Jurnal Indonesia Sosial Teknologi: p-ISSN: 2723 - 6609

e-ISSN : 2745-5254

Vol. 2, No. 2 Februari 2021

\title{
PENGARUH FITUR PRODUK, HARGA DAN PROMOSI TERHADAP KEPUTUSAN PEMBELIAN KARTU PRABAYAR AS PADA MAHASISWA DAN MAHASISWI DI KOTA KENDARI
}

\section{Juwita dan Waode Maratun Shaleha}

Fakultas Eknomi dan Bisnis Islam, Universitas Muhammadiyah Kendari, Kota Kendari, Indonesia

Email: ibujuwita72@gmail.com,wdmaratunshaleha@febi.umkendari.ac.id

\section{Abstract}

The purpose of this research was to determine whether product features, prices and promotions partially have a positive effect on purchasing decisions for AS prepaid cards for college students and female students in Kendari City. This is to find out whether product features, price and promotion simultaneously have a positive effect on purchasing decisions for AS prepaid cards for college students and female students in Kendari City. The population in this study were students and female students in Kendari who used the AS prepaid Telkomsel card. This research is a quantitative research with the object of research on students and female students in Kendari City. The sample in this study amounted to 60 respondents. The sampling technique used in this study is the Accidental Sampling technique and the analytical tool used in this study is multiple linear regression. The results of this study indicate that partially product features have a negative effect on purchasing decisions, prices and promotions have a positive effect on purchasing decisions and simultaneously product features, prices, and promotions have a positive effect on purchasing decisions.

Keyword: product features; price; promotion; purchase decision

\section{Abstrak}

Tujuan penelitian ini adalah untuk mengetahui apakah fitur produk, harga dan promosi secara parsial berpengaruh positif terhadap keputusan pembelian kartu prabayar AS pada mahasiswa dan mahasiswi di Kota Kendari. Untuk mengetahui apakah fitur produk, harga dan promosi secara simultan berpengaruh positif terhadap keputusan pembelian kartu prabayar AS pada mahasiswa dan mahasiswi di Kota Kendari. Populasi dalam penelitian ini adalah mahasiswa dan mahasiswi di Kendari yang menggunakan kartu telkomsel prabayar AS. Penelitian ini adalah penelitian kuantitatif dengan objek penelitian pada mahasiswa dan mahasiswi di Kota Kendari. Sampel dalam penelitian ini berjumlah 60 responden. Adapun teknik pengambilan sampel yang digunakan dalam penelitian ini adalah teknik Accidental Sampling dan alat analisis yang digunakan pada penelitian ini adalah regresi linear berganda. Hasil penelitian ini menunjukkan bahwa secara parsial fitur produk berpengaruh negarif terhadap keputusan pembelian, harga, dan promosi 
berpengaruh positif terhadap keputusan pembelian dan secara simultan fitur produk, harga, dan promosi berpengaruh positif terhadap keputusan pembelian.

Kata kunci: fitur produk; harga; promosi; keputusan pembelian

\section{Pendahuluan}

Perkembangan teknologi dan informasi serta pertumbuhan dan penyebaran penduduk di Indonesia saat ini sangat pesar, sehingga memberikan dampak pada segala aspek kehidupan manusia, salah satunya adalah adanya tuntutan untuk berkomunikasi dengan lancar dalam menyampaikan informasi.

Komunikasi adalah suattu proses pada seseorang yang berusaha untuk memberikan pengertian dan informasi dengan cara menyampaikan pesan kepada orang lain (Ancans, Bobrovs, Ancans, \& Kalibatiene, 2016). Pada era sekarang ini komunikasi tidak cukup hanya dengan komunikasi langsung (Face to face). Sebagian besar bentuk komunikasi sudah dilakukan dengan cara tidak langsung melalui media/alat komunikasi, media komunikasi adalah sarana atau alat yang digunakan untuk untuk berkomunikasi, dalam hal ini merupakan sebuah media yang memfasilitasi keluarga yang termediasi (Prasanti, 2016).

Salah satu media yang digunakan dalam membangun komunikasi salah satunya adalah dengan telepon seluler (handphone). Saat ini handphone merupakan media alat komunikasi terbesar yang digunakan oleh masyarakat (Timbowo, 2016). Saat ini perkembangannya telepon seluler memiliki fungsi yang lebih lengkap dan kompleks.Misalnya, fungsi multimedia pada komputer tidak hanya menjadikannya sebagai alat komunikasi, tetapi juga menjadikannya sebagai perangkat yang kompleks dan cerdas.Tentunya hal ini akan memudahkan konsumen dalam mewujudkan berbagai kepentingan dan kepentingannya kebutuhan.

Lahirnya berbagai kartu seluler atau kartu SIM (Subscriber Identity Module) erat kaitannya dengan perkembangan telepon seluler (telepon genggam) dan kebutuhan masyarakat yang selalu ingin berpindah-pindah. Menyikapi tuntutan tersebut, perusahaan yang bergerak di bidang telekomunikasi berlomba-lomba merilis SIM (Suicide Identity Module) berbasis teknologi GSM (Global System for Mobile Communications). GSM adalah standar global baru dengan kemampuan pemrosesan data yang tinggi. Pada saat ini telepon Global System for Mobile Communication dapat beroperasi pada daerah frekuensi $900 \mathrm{MHz}$ dikembangkan terutama untuk komunikasi suara dan handling data pada kecepatan 9600 bps (Maududy \& Ahyadi, 2018).

Dalam perkembangannya saat ini banyak kita jumpai jenis operator yang mewarnai jaringan telekomunikasi selular berbasis GSM nya di Indonesia, khususnya Indonesia. seperti, Telkomsel (Kartu Halo, Simpati, Kartu AS, LOOP, By.U), Smartfren Telecom (smartfren), Hutchison (three), Indosat Ooredoo (IM3 Ooredoo) dan XL Axiata (XL, XL Prioroitas, AXIS) (Sutarsih, Rozama, Untari, Siswayu, \& Maharani, 2018). Tiga diantaranya merupakan penguasa pasar saat ini yaitu PT Telekomunikasi 
Indonesia Tbk (TLKM), PT XL Axiata Tbk (EXCL), dan PT Indosat Tbk (ISAT). Saat ini, persaingan antar operator semakin sengit, karena semua operator berusaha untuk memasuki pasar dan mendapatkan keuntungan dari pelanggan. Dalam persaingan yang ketat dengan operator kartu seluler dewasa ini, perseroan telah mengadopsi berbagai strategi untuk menarik perhatian konsumen dan mempertahankan pelanggan, mulai dari persaingan harga, persaingan jaringan, persaingan layanan hingga persaingan iklan televisi. (Evelina, Waloejo, \& Listyorini, 2013).

Persaingan di antara operator GSM sangat ketat. Masing-masing perusahaan menyediakan beragam produk kartu seluler prabayar dan pascabayar, dengan berbagai keunggulan baik dari kartu itu sendiri maupun tarifnya. (Wahyuni \& Pardamean, 2016). Banyaknya kartu GSM yang beredar di pasaran, yang berarti memberikan keleluasaan kepada konsumen untuk memilih merek yang sesuai dengan keinginannya. Oleh karena itu, banyak konsumen yang sering berganti operator atau mendapatkan berbagai layanan dari beberapa operator, tujuannya agar komunikasi lebih mudah dan mendapatkan harga yang lebih murah serta layanan yang diberikan, karena tentunya setiap operator memiliki kelebihan dan kekurangannya masing-masing.

Perseroan Terbatas (PT): Telkomsel (biasa disebut Telkomsel) adalah salah satu operator telekomunikasi seluler tertua dan terbesar di Indonesia, yang berfokus pada penyediaan fasilitas komunikasi berbasis teknologi satelit. Telkomsel juga merupakan operator telekomunikasi seluler GSM pertama di Indonesia yang menyediakan layanan pascabayar dan prabayar. Jaringan Telkomsel mencakup seluruh provinsi, wilayah dan semua jalan di Indonesia, dan skalanya telah melampaui para pesaingnya. Kualitas jaringan yang disediakan Telkomsel berstandar dunia, dengan tingkat koneksi 98,66\%, dan akses jaringan dual-band GSM 900, 1800 dan 3G (WCDMA / HSDPA) juga memfasilitasi koneksi. Selain itu, Telkomsel juga menyediakan layanan, layanan transfer pulsa, roaming internasional, layanan 4G world, 5G LTE, NSP, Telkomsel call me, Telkomsel Flash, mobile banking, mobile wallet T-Cash, BlackBerry Internet Service, Telkomsel SMS Me, panggilan tunggu, penerusan panggilan, SMS, MMS dan GPRS, dan ribuan layanan lainnya. Untuk mendukung kebutuhan dan kepuasan pelanggan. Telkomsel juga memiliki fasilitas distribusi yang memudahkan pelanggan mendapatkan layanan, seperti: Call Center, Grai Pari, Halo Outlet, Halo Kiosk, Distributor Outlet dan M-Kiosk.

Telkomsel menawarkan fitur-fitur dengan kebaharuan yang sesuai denga napa yang diinginkan konsumen khususnya pada kalangan mahasiswa. Fitur produk adalah unsur-unsur produk yang dipandang penting oleh konsumen dan dijadikan sebagai dasar pengambilan keputusan (Trivedi \& Raval, 2016). Fitur merupakan sarana kompetitif untuk mendiferensiasikan atau membedakan produk perusahaan dengan produk pesaing (Suhaily \& Darmoyo, 2017). Telkomsel melakukan promosi melalui media cetak dan media elektronik (Imelda \& Sangen, 2013). Unsur bauran pemasaran lainya yang sering 
digunakan dalam persaingan bisnis telekomunikasi saat ini adalah promosi. Promosi merupakan bauran pemasaran yang penting untuk dilaksanakan oleh suatu perusahaan dalam memasarkan produk (Kotler, 2012).

Dalam mempromosikan produk, Telkomsel menggunakan periklanan dan promosi. Promosi adalah untuk mempromosikan atau menyediakan produk atau jasa untuk menarik pelanggan potensial untuk membeli atau mengonsumsi produk atau jasa (Hanaysha, 2018). Dengan adanya promosi, produsen atau distributor mengharapkan kenaikannya angka penjualan (Liu, Zhang, Huang, Zhang, \& Zhao, 2020). Advertising (periklanan) merupakan salah satu bentuk promosi non personal yang menggunakan berbagai media yang dirancang untuk merangsang pembelian. Periklanan dilakukan melalui media cetak (termasuk surat kabar, majalah, tabloid) dan media elektronik (seperti televisi, radio dan internet) (website Telkomsel: www.telkomsel.co.id). Promosi penjualan (sales promotion) Adalah ukuran yang secara langsung merangsang konsumen, dengan tujuan memungkinkan mereka melakukan pembelian lebih cepat. Promosi yang dilakukan Telkomsel antara lain iklan kartu Amerika di media cetak dan elektronik, serta promosi kartu Amerika (sponsorship) di pameran dan acara..

Telkomsel memberikan layanan untuk mendukung produknya seperti: GSM KartuHalo (pascabayar), GSM Simpati (prabayar), GSM Kartu AS (prabayar), Telkomsel Flash (internet), Kartu Facebook dan lain-lainnya. Dari semua produk tersebut, jelas bertujuan untuk memberikan kemudahan dan kenyamanan bagi masyarakat dalam memenuhi kebutuhannya berkomunikasi. Selain memberikan layanan telkomsel juga menawarkan harga yang mudah dijangkau untuk pengisian pulsa prabayarnya. Harga adalah uatu nilai tukar yang bisa disamakan dengan uang atau barang lain untuk manfaat yang diperoleh dari suatu barang atau jasa bagi seseorang atau kelompok pada waktu tertentu dan tempat tertentu (Wadhwa \& Zhang, 2015). Istilah harga digunakan untuk memberikan nilai finansial pada suatu produk barang atau jasa (Karmarkar, Shiv, \& Knutson, 2015). Dalam penelitian ini hanya difokuskan pada kartu prabayar As. Selain itu harga yang ditawarkan oleh Kartu AS juga relatif murah, dan harganya mudah dijangkau oleh mahasiswa sebagai pengguna, harga kartu perdana GSM As yang sangat terjangkau. Kartu GSM As menawarkan harga kartu perdana yang sangat terjangkau dimulai dari harga Rp 6500 sampai Rp 100.000.

Kartu prabayar As diposisikan oleh Telkomsel pada peluncuranya tahun 2004 sebagai kartu seluler GSM yang memberi kualitas terbaik dengan harga terjangkau dibandingkan produk - produk sebelumnya serta dilengkapi dengan layanan andal yang didasarkan pada pemenuhan keinginan konsumen. Adapun jika dibandingkan antara Kartu AS dengan produk operator GSM lainya perbedaan yang kompetitif terletak pada segi kualitas produk dan layanannya. Kartu AS memiliki kualitas jaringan Telkomsel yang mana tidak bisa ditemukan di operator GSM lainya. Dengan kualitas jaringan dimilikinya konsumen tidak harus mengganti kartu seluler yang disebabkan hilangnya koneksi jaringan, konsumen bisa menggunakan Kartu AS dimana saja dan kapan saja 
(Noor, 2016). Tujuan dilakukannya penelitian ini untuk melihat factor-faktor apa saja yang mempengaruhi mahasiswa dan mahasiswi di Kota Kendari dalam melakukan keputusan pembelian karti prabayar As, dengan melihat dari fitur produk, harga, jaringan dan promosi.

Selain itu dari inovasi layanannya Kartu AS juga menawarkan paket-paket menarik yang disesuaikan dengan kebutuhan pelanggannya. Sehingga konsumen bisa menikmati penggunaan Kartu AS dengan tarif yang terjangkau dengan jangkauan yang luas. Diferensiasi produk inilah yang menjadi keunggulan Kartu AS. Walaupun harga keseluruhan yang ditawarkan Kartu AS belum lebih murah. Harga merupakn salah satu factor penentu dalam melakukan keputusan pembelian (Zulaicha \& Irawati, 2016) dibandingkan dengan GSM operator lainya (selalu bersaing) baik itu harga kartu perdana maupun tarif. Keputusan konsumen dalam melakukan pembelian akan dipengaruhi oleh beberapa faktor yang datang dari suatu unit usaha yang mana bisa dikendalikan oleh unit usaha itu sendiri. Sebagai unit usaha yang ingin mempertahankan kelangsungan hidupnya, perusahaan harus mengetahui apa yang menjadi daya tarik konsumen membeli produk Kartu AS, dengan mengetahui apa yang menyebabkan konsumen membeli, maka perusahaan dapat menentukan dan menyusun strategi yang kompetitif, sehingga perusahaan dapat menarik lebih banyak konsumen dan mempertahankan konsumennya.

\section{Metode Penelitian}

Penelitian ini adalah penelitian kuantitatif dengan objek penelitian pada mahasiswa dan mahasiswi di Kota Kendari. Jumlah sampel dalam penelitian ini bersifat infinite (tidak diketahui). Dikarenakan jumlah populasi yang bersifat infinite, maka penenntuan sampel yang digunakan adalah menggunakan accidental sampling, dimana penentuan sampel diambil berdasarkan kebetulan, yaitu mahasiswa dan mahasiswa pengguna kartu prabayar As di Kota Kendari. Adapun jumlah responden dalam penelitian ini berjumlah 60 orang responden. Adapun alat analisis yang digunakan adalah analisis regresi linear berganda. Adapun variabel dalam penelitian ini adalah fitur produk yang diukur dengan tiga indicator yaitu Integritas fungsi kartu Amerika; kemudahan penggunaan fungsi kartu Amerika; konsistensi fungsi dan persyaratan kartu Amerika. Variabel harga diukur dengan tiga indikator yaitu harga GSM sebagai starter pack sangat terjangkau, harga isi ulang sangat bervariasi. Dan suku bunga rendah. Variabel promosi diukur dengan tiga indikator, yaitu iklan kartu Amerika di media cetak dan elektronik; informasi tentang kartu Amerika yang disediakan oleh penjual; dan promosi kartu Amerika (sponsorship) dalam pameran dan acara. Variabel keputusan pembelian diukur dengan lima indikator, yaitu keputusan untuk membeli kartu prabayar (karena saya sangat membutuhkannya); saya sangat aktif mencari informasi tentang konten dan layanan terbaru dari kartu prabayar As; saya mengevaluasi dan 
mempertimbangkan pembelian Kartu As prabayar Manfaatnya sangat teliti, setelah memperhitungkan kebutuhan, mengumpulkan informasi dan mengevaluasi, saya memutuskan untuk membeli kartu As prabayar yang sangat lengkap. Saya puas dengan manfaat dan layanan yang diberikan oleh kartu prabayar As.

\section{Hasil dan Pembahasan}

Tabel 1. Analisis Regresi Linear Berganda Pengaruh fitur produk, harga dan promosi terhadap keputusan pembelian

\begin{tabular}{lccccc}
\hline \multicolumn{1}{c}{ Model } & Sig. & $\mathrm{R}$ & $\mathrm{R}^{2}$ & $\mathrm{~F}$ & Sig \\
& .042 & & & & \\
\hline (Constant) & .011 & & & & \\
Fitur produk (X1) & & .991 & .982 & 768.133 & .000 \\
& .072 & & & & \\
Harga (X2) & .598 & & & & \\
Promosi (X3) & & &
\end{tabular}

\section{Pengaruh fitur produk, harga, dan promosi berpengaruh positif terhadap keputusan pembelian kartu prabayar As}

Berdasarkan hasil penelitian dan analisis data menunjukkan bahwa variabel karakteristik produk (X1), harga (X2) dan promosi (X3) berpengaruh positif terhadap keputusan pembelian (Y). Karena pelajar dan mahasiswi biasa selalu melihat fitur produk apa saja yang disediakan saat membuat keputusan pembelian dengan kartu prabayar AS. Apakah mereka menyediakan fungsi produk sesuai dengan kebutuhannya, seperti M-Banking, T-Cash, 4G LTE, dan kualitas jaringan yang dimilikinya dapat menjangkau seluruh wilayah Kendari. Dari segi harga, harga merupakan salah satu kombinasi pemasaran yang sangat sensitif bagi pelajar dan mahasiswi, karena rata-rata responden dalam penelitian ini adalah pelajar, sehingga mereka lebih memilih untuk menggunakan kartu As prabayar karena berasal dari data pembelian. Sediakan kemasan harga murah untuk isi ulang kartu. Promosi, promosi merupakan salah satu cara Telkomsel memperkenalkan produknya melalui media sosial atau promosi tradisional. Telkomsel menawarkan berbagai kegiatan promosi salah satunya adalah ketengan kuota untuk memenuhi kebutuhan spesifik anda yaitu kuota khusus untuk internet, youtube, instagram dan facebook, dan tentunya harganya yang relatif murah. Selain itu, kegiatan promosi pembelian paket data, paket telepon dan paket SMS juga sangat terjangkau dan dapat memenuhi kebutuhan serta kondisi keuangan para siswa.

\section{Pengaruh Fitur Produk Terhadap Keputusan Pembelian}


Fungsi produk merupakan alat pesaing, yang dapat membedakan produk perusahaan dengan produk sejenis pesaing.Fungsi produk berperan dalam meningkatkan keunggulan utama produk, meskipun kartu GSM As memiliki banyak keunggulan dan keunggulan di produk. Dapat memenuhi kebutuhan konsumen, namun kelengkapan fungsi kartu AS, kemudahan penggunaan fungsi kartu AS dan kesesuaian fungsi kartu AS dengan kebutuhan tidak akan berdampak positif terhadap keputusan pembelian pelajar di Indonesia. Hal ini dikarenakan sebagian besar pelajar tidak terlalu membutuhkan fungsi yang disediakan oleh kartu As prabayar, karena pelajar beranggapan bahwa fungsi produk yang disediakan oleh kartu AS tidak dapat benarbenar memenuhi kebutuhannya, seperti roaming internasional, layanan dunia 3G, NSP, mobile banking, dompet seluler T-Cash, panggilan tunggu, penerusan panggilan, dll.

Mahasiswa dan mahasiswi di Kota Kendari Alasan mengapa mereka tidak memilih fungsi produk karena konsumen kurang memperhatikan fungsi produk dari kartu AS itu sendiri.Mereka menganggap fungsi produk yang disediakan oleh kartu AS prabayar tidak sesuai dengan kebutuhan mereka, seperti roaming internasional, 3G world service, NSP, Mobile banking Business, mobile wallet T-Cash, call waiting, call forwarding, menurut mereka fungsi ini hanya digunakan untuk pebisnis untuk mempromosikan bisnisnya, dan untuk pelajar sebagai konsumen, mereka lebih memperhatikan harga US , promosi dan jaringan. Terjebak dalam membuat keputusan pembelian.

\section{Pengaruh Harga terhadap Keputusan Pembelian}

Harga berpengaruh positif terhadap keputusan pembelian. Hal ini dikarenakan kartu GSM As memberikan harga paket perdana yang sangat terjangkau, sehingga konsumen memilih untuk menggunakan kartu As prabayar, karena harga yang diberikan oleh kartu AS murah dan mudah dijangkau oleh konsumen (khususnya pelajar). Alasan mahasiswa memilih kartu As Prabyar adalah sebagian besar mahasiswa manajemen meyakini bahwa harga merupakan salah satu faktor yang mempengaruhi konsumen dalam mengambil keputusan pembelian, karena harga yang diberikan oleh US Card sendiri murah dan mudah digunakan oleh mahasiswa. Hasil penelitian ini mendukung penelitian-penelitian terdahulu, salah satunya adalah penelitian dari (Sugiyanti, 2017) yang menyatakan bahwa harga merupakan variabel yang paling positif pengaruhnya terhadap keputusan pembelian. Hasil penelitiannya menunjukan bahwa persepsi harga mempengaruhi pelanggan atas keputusan pembelian terhadap kartu perdana produk Telkomsel.

\section{Pengaruh Promosi terhadap Keputusan Pembelian}

Kegiatan promosi berdampak positif terhadap keputusan pembelian Kartu As prabayar bagi pelajar dan pelajar di Kendari, hal ini dikarenakan promosi Kartu As prabayar melalui media cetak dan elektronik membuat Kartu As prabayar mudah 
dikenal oleh masyarakat luas. Melalui informasi kartu AS yang diberikan oleh penjual dan informasi kartu AS yang diberikan oleh penjual, konsumen dapat lebih mudah menemukan konten terbaru dari kartu as tersebut. Dalam pameran dan event (sponsorship) produk Telkomsel, promosi kartu Amerika khususnya kartu as prabayar biasanya dipromosikan dengan mengikuti pameran atau event, dan TSC (Telkomsel School Community) adalah salah satunya. TSC mahasiswa, Telkomsel menyediakan produk kemasan disini, mulai dari kemasan internet sampai telpon sampai sms.

Alasan siswa memilih kartu prabayar As adalah karena sebagian besar konsumen akan membuat keputusan pembelian untuk kartu AS, dan mereka juga akan melihatnya dalam promosi. Bentuk promosi yang mereka berikan antara lain paket telepon ekonomis dan gratis, SMS / MMS, Internet dan kegiatan promosi yang diberikan oleh US Card memungkinkan konsumen untuk melakukan keputusan pembelian atas produk US Card, karena kegiatan promosi penjualan US Card memudahkan konsumen untuk menggunakan sendiri produk US Card tersebut. Selain itu, sebagian besar konsumen hanya ingin dipuaskan dengan satu produk, yang merupakan peran yang dimainkan US Card dalam memenuhi kebutuhan konsumen. Hal ini menunjukkan bahwa pengaruh kegiatan promosi antara lain iklan kartu Amerika di media cetak dan elektronik, informasi tentang kartu Amerika dari penjual, dan promosi kartu Amerika di pameran dan event, yang berdampak positif terhadap keputusan pembelian mahasiswa Kendari.

Hasil penelitian ini mendukung penelitian-penelitian terdahulu (Sugiyanti, 2017) yang menyatakan bahwa promosi berpengaruh positif terhadap keputusan pembelian dan (Titin Purnamasari, Jurnal, titin purnamasari, \& UNHAS, 2011) yang menyatakan bahwa promosi berpengaruh signifikan terhadap keputusan pembelian. Hasil penelitiannya menunjukan bahwa promosi mempengaruhi pelanggan atas keputusan konsumen dalam memilih kartu GSM XL.

\section{Kesimpulan}

Fitur produk, harga, jaringan dan promosi berpengaruh positif terhadap keputusan pembelian kartu prabayar As pada mahasiswa dan mahasiswi di Kota Kendari. Karena itu hipotesis yang peneliti ajukan diterima. Fitur produk tidak berpengaruh positif terhadap keputusan pembelian kartu prabayar As pada mahasiswa dan mahasiswi di Kota Kendari. Karena itu hipotesis yang penulis ajukan peneliti ditolak. Harga berpengaruh positif terhadap keputusan pembelian kartu prabayar As pada mahasiswa dan mahasiswi di Kota Kendari. Karena itu hipotesis yang peneliti ajukan diterima. Promosi berpengaruh positif terhadap keputusan pembelian kartu prabayar As pada mahasiswa dan mahasiswi di Kota Kendari. Karena itu hipotesis yang peneliti ajukan diterima.

\section{Bibliography}


Ancans, guntis, bobrovs, vjaceslavs, ancans, arnis, \& kalibatiene, diana. (2016). Spectrum considerations for $5 \mathrm{~g}$ mobile communication systems. Procedia computer science. Https://doi.org/10.1016/j.procs.2017.01.166

Evelina, nela, waloejo, handoyo djoko, \& listyorini, sari. (2013). Pengaruh citra merek, kualitas produk, harga, dan promosi terhadap keputusan pembelian kartu perdana telkomflexi (studi kasus pada konsumen telkomflexi di kecamatan kota kudus kabupaten kudus). Jurnal ilmu administrasi bisnis, 1(1), 203-213.

Hanaysha, jalal rajeh. (2018). An examination of the factors affecting consumer's purchase decision in the malaysian retail market. Psu research review. Https://doi.org/10.1108/prr-08-2017-0034

Imelda, sri, \& sangen, marijati. (2013). Pengaruh keputusan bauran promosi terhadap pengambilan keputusan pembelian nomor perdana telkom flexi di kota banjarmasin. Jurnal wawasan manajemen, 1(2), 259-280.

Karmarkar, uma r., shiv, baba, \& knutson, brian. (2015). Cost conscious? The neural and behavioral impact of price primacy on decision making. Journal of marketing research. Https://doi.org/10.1509/jmr.13.0488

Kotler, philip. (2012). Marketing management/philip kotler, kevin lane keller. Pearson education international.

Liu, qihua, zhang, xiaoyu, huang, shan, zhang, liyi, \& zhao, yang. (2020). Exploring consumers' buying behavior in a large online promotion activity: the role of psychological distance and involvement. Journal of theoretical and applied electronic commerce research. Https://doi.org/10.4067/s071818762020000100106

Maududy, ivan, \& ahyadi, zaiyan. (2018). Perkembangan teknologi jaringan gsm dalam komunikasi seluler. Jurnal poros teknik, 10(2), 73-81.

Noor, nela prahesty. (2016). Pengaruh bauran pemasaran (marketing mix) terhadap keputusan pembelian konsumen kartu indosat (studi empiris pada mahasiswa fakultas ekonomi universitas muria kudus). Skripsi.

Prasanti, ditha. (2016). Perubahan media komunikasi dalam pola komunikasi keluarga di era digital. Jurnal commed, 1(1), 2527-8673.

Sugiyanti. (2017). Pengaruh bauran pemasaran terhadap keputusan membeli kartu perdana produk telkomsel di samarinda. Ilmu dan riset manajemen, 2(9), 1-18.

Suhaily, lily, \& darmoyo, syarief. (2017). Effect of product quality, perceived price and Jurnal Indonesia Sosial Teknologi, Vol. 2, No. 2, Februari 2021 
brand image on purchase decision mediated by customer trust (study on japanese brand electronic product). Jurnal manajemen. Https://doi.org/10.24912/jm.v21i2.230

Sutarsih, tri, rozama, nur anggraini, untari, rima, siswayu, gusnisa, \& maharani, karmila. (2018). Statistik telekomunikasi indonesia 2018. In badan pusat statistik.

Timbowo, deify. (2016). Manfaat penggunaan smartphone sebagai media komunikasi (studi pada mahasiswa jurusan ilmu komunikasi fakultas ilmu sosial dan politik universitas sam ratulangi). E-journal "acta diurna," v(2), 1-13.

Titin purnamasari, jurnal, pemasaran, titin purnamasari, program manajemen, \& unhas, universitas. (2011). Analisis faktor-faktor yang mempengaruhi keputusan dalam memilih kartu gsm xl pada pt exelcomindo, tbk makassar. 1(1), 1-9.

Trivedi, rinky, \& raval, rahul. (2016). Consumer buying intentions towards smartphones : a conceptual framework. International journal of applied research.

Wadhwa, monica, \& zhang, kuangjie. (2015). This number just feels right: the impact of roundedness of price numbers on product evaluations. Journal of consumer research. Https://doi.org/10.1086/678484

Wahyuni, sri, \& pardamean, jonianto. (2016). Pengaruh iklan, harga dan kualitas layanan terhadap keputusan pembelian kartu simpati di institute perbanas. Jurnal studi manajemen dan bisnis.

Zulaicha, santri, \& irawati, rusda. (2016). Pengaruh produk dan harga terhadap keputusan pembelian konsumen di morning bakery batam. Inovbiz: jurnal inovasi bisnis. Https://doi.org/10.35314/inovbiz.v4i2.76 